\title{
Scientific Project Learning: Bagaimana Model Pembelajaran Tersebut Meningkatkan Keterampilan Proses Sains Dan Motivasi Siswa Terhadap Materi Fisika?
}

\author{
Siswanto, Manurung I.F.U., Kamisani N., Wulandari C., Lumbantobing S.S., * \\ *Mahasiswa S2 Pendidikan Fisika, \\ Universitas Pendidikan Indonesia, \\ Bandung, Jawa Barat. \\ Email: sis_physics@yahoo.com
}

\begin{abstract}
Abstrak. Penelitian ini bertujuan untuk meningkatan keterampilan proses sains siswa serta motivasi siswa terhadap mata pelajaran fisika melalui penerapan model scientific project learning. Project yang diberikan kepada siswa yaitu membuat sebuah alat yang dapat menjelaskan konsep tekanan hidrostatis. Model ini diterapkan berdasarkan pada hakikat pembelajaran sains yaitu sebagai proses dan produk. Penelitian ini menggunakan desain penelitian one group pretest posttest design, dimana populasinya yaitu seluruh siswa kelas VIII salah satu SMP di kabupaten Grobogan. Sampel diambil secara acak sebanyak 30 siswa. Data dikumpulkan menggunakan wawancara, lembar observasi, dan test. Hasil penelitian menunjukan bahwa melalui penerapan scientific project learning, terdapat peningkatan keterampilan proses sains siswa secara signifikan, yaitu diperoleh nilai peningkatan rerata N-Gain sebesar 0.44. Selain itu, melalui penerapan model pembelajaran ini, siswa menjadi lebih termotivasi untuk belajar fisika. Siswa merasa bahwa fisika yang menurut mereka sulit, menjadi lebih mudah dipelajari karena pemahaman materi dilakukan melalui fenomena yang ditunjukan oleh alat yang mereka buat.
\end{abstract}

Kata Kunci : scientific project learning, keterampilan proses sains, motivasi siswa.

\section{PENDAHULUAN}

Sains merupakan bagian dari pembelajaran di setiap sekolah. Namun pemahaman dan rasa ingin tahu mengenai sains di kalangan siswa masih rendah. Kita tahu pada era ini, perkembangan ilmu pengetahuan dan teknologi tidak terlepas dari Ilmu Pengetahuan Alam (IPA) atau sains. Fisika adalah bagian dari pembelajaran IPA yang memiliki peranan penting dalam mengikuti dan mengembangkan IPTEK. Oleh karena itu, dalam memacu ilmu pengetahuan dan teknologi, proses pembelajaran fisika perlu mendapat perhatian yang lebih.

Pembelajaran IPA sangat ditekankan untuk melakukan kegiatan yang sesuai dengan bagaimana ilmu tersebut diperoleh. Misalnya dengan melakukan observasi, percobaan atau kegiatan praktikum yang pada intinya mengarah pada pembelajaran berbasis inquiri.

IPA-Fisika adalah ilmu pengetahuan yang menggunakan metode ilmiah dalam prosesnya. Dengan demikian, proses pembelajaran fisika bukan hanya memahami konsep-konsep fisika semata, melainkan juga mengajar siswa berpikir konstruktif melalui fisika sebagai keterampilan proses sains (KPS), sehingga pemahaman siswa terhadap hakikat fisika menjadi utuh, baik sebagai proses maupun sebagai produk. Melalui peningkatan keterampilan proses sains diharapkan dapat terwujudnya generasi bangsa yang mampu bersaing pada tataran dunia globalisasi.

Rustaman (2006) mengemukakan bahwa keterampilan dasar bekerja ilmiah terdiri atas kecerdasan emosional dan kecerdasan intelektual. Kecerdasan intelektual sebagian besar merupakan keterampilan proses sains (KPS) pada pendidikan dasar dan menengah. 
Dalam pembelajaran sains khususnya Fisika, proses pembelajaran tidak terlepas dari pengembangan keterampilan proses sains. Hal ini terbukti dari beberapa kompetensi yang secara jelas menuntut mengembangkan keterampilan proses sains.

Pada praktiknya, dalam pengembangan keterampilan proses sains, juga dibutuhkan motivasi siswa yang tinggi untuk belajar. Oleh sebab itu, pengembangan motivasi juga perlu dilakukan untuk menumbuhkan rasa ketertarikan dan semangat siswa untuk belajar dan mengikuti proses pembelajaran. Motivasi yang timbul dalam diri maupun dari luar diri siswa sangat membantu dalam proses pembelajaran (Mary Hanrahan,1998). Oleh sebab itu, model pembelajaran dikelas harus dirancang untuk meningatkan minat dan motivasi belajar siswa (Teresa Larkin-Hein, 2000).

Menurut Aditia Krisnawati (dalam Aris Prasetyo Nugroho, 2013:12) motivasi belajar siswa dalam pembelajaran fisika masih sangat rendah sehingga akan mengakibatkan prestasi belajar menurun. Oleh karena itu motivasi merupakan faktor penting yang diperlukan untuk meningkatkan kualitas belajar siswa.

Berdasarkan wawancara yang dilakukan peneliti kepada beberapa siswa, menunjukkan bahwa siswa ternyata kurang tertarik untuk belajar fisika. Kebanyakan siswa merasa bahwa fisika sangat sulit untuk dipahami. Hal ini menyebabkan siswa menjadi kurang termotivasi untuk mengikuti proses belajar mengajar. Kemudian, siswa menjelaskan bahwa proses pembelajaran yang dilakukan dirasa kurang menarik, sehingga siswa menjadi tidak termotivasi untuk mengikuti proses pembelajaran.

Berdasarkan hal tersebut, maka peneliti melakukan sebuah inovasu pembelajaran sains yang menekankan pada pemberian proyek yang harus diselesaikan siswa. Inovasi pembelajaran yang dilakukan yaitu Scientific Project Learning.

Scientific Project Learning merupakan sebuah metode pembelajaran yang melibatkan keaktifan siswa dalam pembelajarannya. Pada metode ini, menggunakan teknik Laboratory setting yang menitikberatkan pada produk berupa proyek yang dikerjakan oleh siswa. Metode pembelajaran ini dapat memacu siswa untuk aktif dalam proses pembelajaran. Menurut Baran dan Maskan (2010) bahwa pembelajaran proyek secara umum dapat membuat siswa menjadi lebih menikmati proses pembelajaran yang dilakukan, siswa menjadi lebih aktif, serta dapat meningkatkan rasa percaya diri siswa.

Beberapa penelitian tentang pembelajaran sains yang menekankan pada pemberian proyek juga menunjukan hasil yang positif, terutama dalam meningkatkan beberapa kemampuan dan keterampilan dalam diri siswa. Menurut Colley dan Kabba (2008), bahwa pembelajaran proyek dapat membantu meningkatkan pemahaman konsep sains siswa. Selain itu, pembelajaran yang menekankan pada pemberian proyek dapat meningkatkan berbagai keterampilan siswa, sikap siswa, dan pemahaman konsep fisika (Yalcin, 2009; Hussain, 2011).

Secara umum, berdasarkan studi literatur yang dilakukan peneliti, menunjukan hasil bahwa pembelajaran sains yang menggunakan metode pemberian proyek dapat mendukung untuk meningkatkan beberapa keterampilan yang ada dalam diri siswa serta rasa ketertarikan siswa untuk mengikuti proses pembelajaran.

Pada penelitian ini, sintaks pembelajaran model scientific projecct learning di bagi dalam lima tahap. Tahap-tahap tersebut yaitu (1) Tahap pembentukan kelompok, (2) Tahap pemberian proyek, berupa pemberian suatu masalah yang dapat memunculkan miskonsepsi yang berkaitan dengan sains, sehingga dapat memotivasi siswa untuk menyelesaikan masalah tersebut, (3) Tahap penanaman konsep, (4) Tahap pertanggung jawaban proyek berupa presentasi tugas di depan kelas oleh masing-masing kelompok, (5) Tahap pemberian test.

Berdasarkan uraian di atas, maka penelitian ini bertujuan untuk (1) mengembankan model pembelajaran Scientific Project Learning untuk meningkatkan keterampilan proses sains dan motivasi siswa terhadap mata pelajaran fisika, (2) meningkatkan keterampilan proses sains dan motivasi siswa terhadap mata pelajaran fisika. 


\section{METODE}

Penelitian ini, menggunakan metode pre experiment. Metode ini dipilih karena sesuai dengan tujuan penelitian yang hanya ingin melihat bagaimana penerapan Scientific Project Learning dapat meningkatkan keterampilan proses sains dan motivasi siswa. Desain penelitian yang digunakan yaitu one group pretest posttest design. Desain ini hanya menggunakan satu kelompok eksperimen tanpa ada kelompok pembanding. Sampel penelitian dipilih dengan simple random sampling, dimana populasinya yaitu seluruh siswa kelas VIII salah satu SMP di kabupaten Grobogan dan sampel diambil secara acak sebanyak 30 siswa.

Instrumen yang digunakan dalam penelitian ini adalah : (1) Test; digunakan untuk mengukur dan melihat peningkatan keterampilan proses sains siswa. Keterampilan proses sains yang ditingkatkan yaitu keterampilan mengamati, menyusun hipotesis, merencanakan pecobaan, menerapkan konsep, menyimpulkan, dan mengkomunikasikan baik verbal maupun non verbal. Tes dilaksanakan sebelum pembelajaran (pretes) dan setelah pembelajaran (postes). (2) Lembar observasi; digunakan untuk mengukur proses keterlaksanaan pembelajaran yang dilakukan oleh guru, serta digunakan untuk melihat motivasi siswa dalam mengikuti proses pembelajaran. Aspek motivasi yang diamati meliputi empat aspek, yaitu aspek percaya diri, perhatian, relevansi, dan kepuasaan (Suprijono, 2010). (3) Wawancara; digunakan untuk mewawancarai beberapa siswa yang dijadikan sebagai sampel untuk dimintai keterangan tentang tanggapan siswa selama mengikuti proses kegiatan belajar mengajar menggunakan model scientific project learning.

Untuk menghitung peningkatan keterampilan proses sains siswa, digunakan rumus faktor gain yang dinormalkan yang dihitung sesuai dengan yang dikemukakan oleh Hake (1998), yaitu:

$$
g=\frac{\% \text { postest }-\% \text { pretest }}{\% 100-\% \text { pretest }}
$$

Keterangan:

$\%$ postest $=$ skor postest

$\%$ pretest $=$ skor pretest

dengan kriteria tingkat gain adalah: a) g $\leq 0,30$

: rendah, b) $0,30 \leq \mathrm{g} \geq 0,70$ : sedang, c) $\mathrm{g} \geq 0,70$

: tinggi.

\section{HASIL DAN PEMBAHASAN}

Karakteristik model pembelajaran scientific project learning adalah adanya produk berupa proyek yang diberikan guru kepada siswa. Produk yang ditugaskan kepada siswa berkaitan dengan sains. Sehingga, model ini sangat sesuai jika dikaitkan dengan pembelajaran IPA khususnya Fisika yang pada hakikatnya berorientasi pada proses dan produk. Model scientific project learning yang diterapkan dalam penelitian ini memiliki beberapa tahapan-tahapan, dimana tahapantahapan yang dilakukan mendukung dan sesuai dengan tujuan penelitian yang dilakukan yaitu untuk meningkatkan keterampilan proses sains dan motivasi siswa.

Pada tahap pertama, guru membentuk kelompok. Dalam proses belajar mengajar, guru membagi siswa menjadi lima kelompok, dimana masing-masing kelompok terdiri dari 6 siswa. Kemudian, pada tahap ke dua, guru memberikan sebuah permasalahan kepada siswa yang berkaitan dengan Fisika, yaitu pada konsep tekanan hidrostatis. Permasalahan yang diberikan merupakan sebuah permasalahan yang dapat menimbulkan sebuah miskonsepsi dalam diri siswa yang ada pada materi tekanan Hidrostatis. Kemudian, siswa diberi motivasi untuk menjawab permasalahan yang diberikan melalui pembuatan sebuah alat yang dapat menjelaskan konsep dari permasalahan tersebut. Pada tahapan ini, dapat menumbuhkan rasa ingin tahu siswa, sehingga siswa menjadi lebih termotivasi untuk mencari jawaban dari masalah tersebut.

Pembuatan proyek yang dilakukan siswa, dapat melatihkan siswa beberapa keterampilan proses. Beberapa keterampilan tersebut yaitu: keterampilan mengamati, menyusun hipotesis, merencanakan pecobaan, menerapkan konsep, menyimpulkan, dan 
mengkomunikasikan baik verbal maupun non verbal.

Selanjutnya, tahap ke tiga merupakan tahap penanaman konsep. Pada tahap ini, proses pembelajaran dilakukan guru di dalam kelas dengan menggunakan metode demonstrasi. Siswa dibekali beberapa konsep dasar yang berkaitan dengan materi yang sedang dipelajari, serta menjadi dasar bagi siswa dalam menyelesaikan proyek yang mereka buat.

Pada tahap berikutnya yaitu tahap pertanggungjawaban proyek. Pada tahap ini, siswa mempresentasikan hasil analisisnya mengenai proyek dan permasalahan yang mereka buat. Setiap kelompok mempresentasikan hasil pengamatan dan analisisnya, kemudian ditanggapi oleh kelompok lainnya. Pada tahap ini, guru berperan sebagai fasilitator untuk memfasilitasi jalannya diskusi yang dilakukan oleh siswa.

Tahap terakhir yaitu tahap pemberian test. Tahap ini dilakukan untuk mengetahui penguasaan keterampilan proses sains yang ada dalam diri siswa, sekaligus untuk mengetahui sejauh mana siswa memahami dan menguasai konsep yang sudah dipelajari siswa.

TABEL 1. Hasil Uji Peningkatan Rata-Rata Keterampilan Proses Sains Siswa

\begin{tabular}{|c|c|c|c|c|}
\hline \multirow{2}{*}{ Jenis Keterampilan } & \multicolumn{2}{|c|}{ Rata-rata Skor } & \multirow{2}{*}{$\langle\mathrm{g}\rangle$} & \multirow{2}{*}{ Kategor } \\
\hline & Pretest & Postest & & \\
\hline mengamati & 2,13 & 4,12 & 0,69 & Sedang \\
\hline menyusun hipotesis & 1,23 & 2,53 & 0,34 & Sedang \\
\hline merencanakan percobaan & 1,11 & 1,71 & 0,15 & Rendah \\
\hline menerapkan konsep & 1,03 & 3,11 & 0,51 & Sedang \\
\hline menyimpulkan & 2,33 & 3,63 & 0,48 & Sedang \\
\hline mengkomunikasikan & 1,95 & 3,57 & 0,53 & Sedang \\
\hline Rata-rata & 1,63 & 3,11 & 0,44 & Sedang \\
\hline
\end{tabular}

Tabel 2. Lembar Observasi Motivasi Siswa Terhadap Proses Belajar Mengajar

\begin{tabular}{cc}
\hline Aspek yang diamati & Persentase jawaban observer \\
\hline Percaya diri & $84 \%$ \\
Perhatian & $92 \%$ \\
Relevansi & $88 \%$ \\
Kepuasan & $96 \%$ \\
\hline
\end{tabular}

Berdasarkan Tabel 1. menunjukan bahwa proses pembelajaran yang menggunakan model scientific project learning dapat meningatkan keterampilan proses sains siswa. Berdasarkan hasil analisis menggunakan $\mathrm{N}$-gain menunjukan bahwa peningkatan rata-rata keseluruhan dari keterampilan proses sains yang diukur sebesar 0,44 dan termasuk dalam kategori sedang. Keterampilan proses sains yang diukur berupa keterampilan mengamati, menyusun hipotesis, merencanakan pecobaan, menerapkan konsep, menyimpulkan, dan mengkomunikasikan baik verbal maupun non verbal.

Berdasarkan hasil tersebut, terlihat bahwa keterampilan merencanakan percobaan mendapat nilai $\mathrm{N}$-gain yang paling kecil yaitu sebesar 0,15 dan termasuk dalam kategori rendah. Setelah peneliti menganalisis data pendukung yang lain, yaitu dari hasil wawancara dan lembar observasi, rendahnya peningkatan disebabkan karena siswa tidak terbiasa dalam melaksanakan eksperimen.

Proses pembelajaran yang dilakukan oleh guru, ternyata lebih menekankan pada aktivitas siswa mengerjakan soal untuk melatih pemahaman konsepnya. Selain itu, rendahnya nilai peningkatan pada keterampilan merancang percobaan disebabkan karena guru kurang terampil dalam menjelaskan sebuah materi dengan menggunakan sebuah fenomena atau eksperimen sederhana. Data ini diperoleh melalui observasi yang dilaksanakan oleh observer terhadap guru.

Kemudian, berdasarkan lembar observasi yang di isi oleh 5 observer, menunjukan hasil bahwa dalam proses pembelajaran, siswa lebih termotivasi untuk 
mengikuti proses belajar mengajar. Aspek yang diamati untuk menunjukan tingginya motivasi siswa terhadap proses belajar mengajar, yaitu: aspek percaya diri, perhatian, relevansi, dan kepuasan. Hasil observasi dapat dilihat pada Tabel 2.

Aspek paling tinggi yaitu pada aspek kepuasan. Siswa merasa puas mengikuti proses belajar mengajar menggunakan model yang scientific project learning. Hasil ini juga didukung oleh hasil wawancara yang dilakukan oleh peneliti secara terbuka kepada beberapa siswa. Wawancara dilakukan dengan mengacu pada aspek-aspek yang ada dalam lembar observasi. Siswa merasa bahwa proses pembelajaran yang dilakukan bermakna bagi mereka. Mereka menjadi lebih mudah memahami konsep yang dipelajari. Aspek kedua yang dominan adalah aspek perhatian. Hal ini terjadi karena proses pembelajaran terpusat pada siswa melalui presentasi hasil proyek yang sudah dilaksanakan. Hal ini selaras dengan jawaban siswa pada saat dilakukan wawancara. Siswa merasa bahwa proses pembelajaran yang dilakukan lebih memberikan kebebasan kepada siswa sehingga siswa lebih terfokus dalam menyelesaikan pekerjaan dan tugasnya.

Kemudian, pada dua aspek yang lain yaitu aspek percaya diri dan aspek relevansi, hasil observasi pun menunjukan bahwa siswa memiliki rasa percaya diri dan mampu mengkaitkan antar berbagai konsep yang dipelajari. Berdasarkan observasi yang dilakukan, siswa lebih berani dan lebih aktif. Ketika diberi kesempatan bertanya, siswa berebut untuk mengajukan pertanyaan. Selain itu, keaktifan siswa ditunjukan dengan lancarnya proses diskusi yang dilakukan. Ada timbal balik antara siswa yang menjadi penyaji dengan siswa yang menjadi peserta. Ketika penyaji tidak bisa menjawab pertanyaan yang ditanyakan peserta, ada beberapa peserta yang membantu penyaji menjawab pertanyaan. Hal ini menunjukan bahwa siswa menjadi percaya diri dan memiliki aspek relevansi yang besar.

Pada penelitian ini, peneliti melakukan wawancara kepada siswa untuk mengetahui tanggapan siswa terhadap proses pembelajara. Menurut siswa, proses pembelajaran menjadi lebih menarik sehingga siswa tidak merasa bosan dan jenuh mengikuti proses pembelajaran. Akan tetapi, ada beberapa kendala dalam proses pembelajaran ini yang dikeluhkan siswa. Siswa merasa kesulitan untuk merancang percobaan dengan menggunakan alat yang mereka buat sendiri. Hal ini ternyata sesuai dengan hasil test yang dilakukan untuk mengukur peningkatan keterampilan proses sains siswa, dimana pada aspek keterampilan merancang percobaan mendapatkan kategori peningkatan yang rendah. Sehingga, hal ini dapat menjadi pokok permasalahan utama yang dapat dikaji untuk penelitian selanjutnya.

\section{PENUTUP}

Berdasarkan temuan pada kegiatan penelitian, dapat disimpulkan bahwa model pembelajaran Scientific Project Learning dapat digunakan untuk meningkatkan keterampilan proses sains serta memotivasi siswa untuk belajar sains khususnya fisika. Sintaks pembelajaran yang dilakukan terdiri dari lima tahapan. Kelima tahapan tersebut yaitu: (a) tahap pembagian kelompok; (b) tahap pemberian proyek melalui suatu masalah yang dapat menjadikan miskonsepsi dalam diri siswa, sehingga melalui proyek yang dibuat, siswa dapat mengatasi miskonsepsi yang ada dalam diri mereka sendiri; (c) tahap penanaman konsep; (d) tahap pertanggungjawaban proyek berupa presentasi laporan proyek yang sudah dibuat; (e) tahap pemberian test atau penilaian.

Selain itu, berdasarkan hasil analisis data yang sudah diolah peneliti bahwa peningkatan rata-rata dari keterampilan proses sains dengan menggunakan uji $\mathrm{N}$-gain mencapai skor 0,44 yang termasuk kriteria sedang. Beberapa keterampilan tersebut yaitu keterampilan mengamati, menyusun hipotesis, merencanakan pecobaan, menerapkan konsep, menyimpulkan, dan mengkomunikasikan baik verbal maupun non verbal. Selain itu, siswa juga menjadi termotivasi untuk mengikuti proses kegiatan belajar mengajar.

Berdasarkan penelitian ini, peneliti menyarankan bahwa guru harus memfasilitasi siswa untuk dibiasakan melakukan percobaan yang dapat mendukung konsep yang akan dipelajari. Temuan dalam penelitian ini 
menunjukan bahwa peningkatan keterampilan siswa untuk menyusun percobaan termasuk dalam kategori rendah.

\section{UCAPAN TERIMAKASIH}

Ucapan terimakasih peneliti sampaikan kepada semua pihak yang sudah membantu dalam penelitian ini, terutama guru Fisika dan Ibu Kepala SMP tempat penelitian dilakukan. Semoga hasil penelitian ini dapat bermanfaat bagi semua pihak yang membutuhkan.

\section{DAFTAR PUSTAKA}

Baran, M. \& Maskan, A. 2010. The effect of project-based learning on pre-service physics teachers electrostatic achievements. Cypriot Journal of Educational Sciences, 5: 242-257.

Colley, E.D. \& Kabba, E. 2008. "Project based science instruction", George Mason University, America.

Hake, R.R. 1998. Interactive-engagement vs traditional methods: A six thousand student survey of mechanic test data for introductory physics courses. Journal of Physics. 66 (1): 64-74.

Hanrahan, M.1998. The effect of learning environment factors on students' motivation and learning. International Journal of Science Education 20 (6) p 737-753.
Hein T-L,. 2000. Learning Styles in Introductory Physics: Enhancing Student Motivation, Interest, \& Learning. International Conference on Engineering and Computer Education S’o Paulo, Brazil.

Husain, S., Muben, S. \& Tariq, S. 2011. The Effectiveness of Teaching Physics through Project Method on Academic Achievement of Students at Secondary Level -A Case Study. Journal of Education and Practice, Vol 2, No 8 : 28-34.

Nugroho, A.P, et.al. 2013. Pengembangan Media Pembelajaran Fisika Menggunakan Permainan Ular Tangga ditinjau dari Motivasi Belajar Siswa Kelas VIII Materi Gaya. Jurnal Pendidikan Fisika Vol.1 No.1:12.

Rustaman,Y.N. et.al. 2006. Strategi Belajar Mengajar Biologi. Common TextBook JICA Edisi Revisi. Bandung: Jurusan Pendidikan Biologi FPMIPA UPI.

Suprijono, A., 2010, Cooperative Learning, Pustaka Pelajar, Yogyakarta.

Yalcin, A.S., Turgut, U. \& Buyyukasap, E. 2009. The Effect of Project Based Learning on Science Undergraduates' Learning of Electricity, Attitude towards Physics and Scientific Process Skills. International Online Journal of Educational Sciences, 1(1): 81-105. 